\title{
Exploring the Reduction of Pollutant and Greenhouse Gas Emissions by Utilizing Solar Zero Energy Buildings in Iran
}

\author{
J. Eshraghi, N. Mirkhani, N. Narjabadifam, S. Sadoughi, and M. Ashjaee
}

\begin{abstract}
Systems utilizing renewable energies can provide clean, reliable, secure and competitive energy products to help meet the rapidly increasing global energy demand. This paper explores the reduction of pollutant and greenhouse gas emissions by utilizing solar Zero Energy Building (ZEB) for a typical detached house in Tehran. Brief description about the design of such a building is presented. Regarding the fact that electricity and natural gas consumption are covering $75 \%$ of building energy consumption in Iran, this analysis includes two points of view, a direct and an indirect one. Direct analysis is conducted by investigation of consumption of natural gases in conventional homes while electricity generation at power plants requires indirect analysis in order to calculate consequent pollution elimination. Finally, the reduction of social costs which go along with reduction in pollutant and greenhouse gas emissions, are investigated. Results suggest that implementation of a ZEB in Iran reduce pollutants and greenhouse gases up to $4759 \mathrm{~kg}$ of $\mathrm{CO}_{2}$ per family annually.
\end{abstract}

Index Terms-Pollutants and greenhouse gases, social costs, zero energy building for Tehran.

\section{INTRODUCTION}

The effect of increasing concentrations of pollutants and greenhouse gases in the atmosphere is considered to be one of the most serious threats to the global environment. The present energy use pattern in the world is characterized by a dependence on fossil fuels. The future global economy is likely to consume even more energy, especially with the rising energy demand of developing countries. At the same time, the tremendous risk of climate change associated with the use of fossil fuels makes supplying this energy increasingly difficult. Therefore the world is facing a very serious environmental crisis.

In Iran, $36.25 \%$ of energy usage belongs to the buildings. This is equal to consumption of 432.4 million barrels of crude oil. The quota of each energy supplier in buildings' energy usage is illustrated in Fig. 1. Also buildings are responsible for $25 \%$ of greenhouse gas emissions due to using natural gas and oil products. In order to clarify the role which buildings play in $\mathrm{CO}_{2}$ emission, amount of $\mathrm{CO}_{2}$ emission of each energy consumer in Iran is illustrated in Fig. 2 [1].

Manuscript received October 25, 2013; revised January 13, 2014. This work was supported in part by the University of Tehran, Department of Mechanical Engineering.

The authors are with the Department of Mechanical Engineering, University of Tehran (e-mail: eshraghijavad@gmail.com, s.n.mirkhani@gmail.com, saghi.sadoughi@ut.ac.ir, ashjaee@ut.ac.ir).

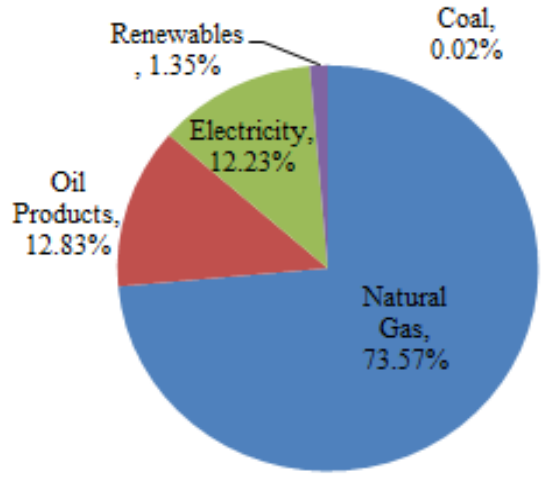

Fig. 1. Quota of each energy supplier in providing the demand of the buildings in Iran.

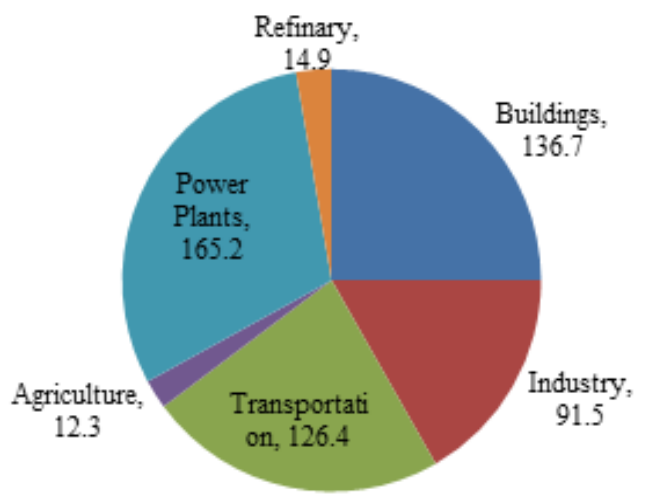

Fig. 2. Amount of $\mathrm{CO}_{2}$ emission of each energy consumer in Iran (Million tons).

In addition $\mathrm{CO}_{2}$ emission is $7279 \mathrm{~kg}$ per capita. Table I indicates the amount of other pollutant and greenhouse gas emissions per capita in Iran [1].

TABLE I: POLLUTANT AND GREENHOUSE GAS EMISSIONS IN IRAN (KG CO PER CAPITA) [1]

\begin{tabular}{c|cccccccc}
\hline Pollutant & $\mathrm{NO}_{\mathrm{X}}$ & $\mathrm{SO}_{2}$ & $\mathrm{SO}_{3}$ & $\mathrm{CO}$ & $\mathrm{SPM}$ & $\mathrm{CO}_{2}$ & $\mathrm{CH}_{4}$ & $\mathrm{~N}_{2} \mathrm{O}$ \\
\hline Amount & 24.5 & 19 & 0.2 & 107 & 5.2 & 7279 & 0.7 & 0.2 \\
\hline
\end{tabular}

There are two important solutions in order to control the pollutants and greenhouse gases. Reduction in growing energy demand through improved energy efficient buildings and conservation is the one. Research, develop, and deploying a broad range of energy sources to work with properly functioning global markets in order to help meet future energy demands, can be the other solution. Therefore, it is essential to take actions towards finding alternative sources of energy as well as conserving non-renewable energy resources. Solar energy is the solution for the world's energy requirements and is the way of the future. Green and energy efficient buildings such as ZEBs make it possible to preserve natural resources 
for the next generations by reducing pollution and increasing ecosystem self-recovery. However, ZEB is not widely spread in Iran because of its low economic efficiency.

In this paper, we have tried to study the effects of employing a ZEB in Tehran on environment and specially pollutant and greenhouse gas emissions. The designed building features have been described in the following as the first step. Afterward, the effect of using ZEBs as a substitute for conventional homes is investigated in environmental aspect. This work is done through the estimation of pollutants generation due to domestic use of natural gas and electricity for a typical year. Finally, another aspect of this elimination of pollutants is studied in the form of social costs which is imposed on a community.

\section{DESCRIPTION OF THE CASE STUDY}

In this 96 square meters home, solar energy is the main supply which provides thermal comfort, hot water and electricity needs, using combination of collectors and photovoltaic panels. In order to achieve a super insulated home, special insulations and roller shading is used. Applying sunspace in southern side of the house, as a passive strategy, make a reduction of $20 \%$ in winter energy demand of the house [2]. Moderately warm climate in Tehran assigns the HVAC requirement in active and passive form. An absorption chiller as an active system has been utilized to support both heating and cooling. Optimized combination of flat-plate and evacuated collectors balances the collectors' efficiencies during the year. Domestic hot water demand (DHW) is also supplied in part of designed absorption cycle to reduce the size of the equipment and consequently decrease the costs. In case of inadequate radiation, auxiliary system contributes the main system to meet the demands of this home. Four batteries are used to save energy from PV cells for critical conditions such as night-time or cloudy days. To decrease energy consumption, LEDs and fiber optics used in lighting system. Fiber optics can transmit natural sunlight to the inner spaces of the house. Off-grid solar photovoltaic system has been chosen for energy storage. Stored energy utilized in appliances, lighting, HVAC auxiliary system and controllers [3].

\section{A. Architecture and Passive Strategies}

To use solar energy in natural lighting and thermal comfort, passive design strategies have key roles. Large glazed south-facing windows are used to gain the direct solar energy for natural lighting and thermal needs. Shading and thermal mass used in dining room and kitchen maintain the home from overheating. The area of south-facing window is about 9 percent of floor area. A sunspace, a closed, southbound volume, constituted by transparent surfaces, adjacent to a building, reduces winter energy demand thanks to the use of solar gains. Also, all south-facing windows are shaded by roller-shading. Creating super insulation conditions is followed in this project strongly by choosing materials with low overall heat transfer coefficient which are mentioned in Table II. This study builds on a $96 \mathrm{~m}^{2}\left(12^{\mathrm{m}} \times 8^{\mathrm{m}}\right)$, single-story house with two bedrooms. The house plan has illustrated in the Fig. 3 [3].
TABLE I: BUILDING CONSTRUCTION MATERIALS

\begin{tabular}{l|l}
\hline Building Elements & Materials \\
\hline External Walls & $\begin{array}{l}100 \mathrm{~mm} \text { polyurethane, 120 mm } \\
\text { glass wool, 10 mm plaster, 20 mm } \\
\text { thermo wood }\end{array}$ \\
\hline Glazing & $\begin{array}{l}\text { Double insulating glass (suspended } \\
\text { film and low-E) }\end{array}$ \\
\hline Internal Walls & $\begin{array}{l}20 \mathrm{~mm} \text { Plasterboard, } 50 \mathrm{~mm} \text { glass } \\
\text { wool }\end{array}$ \\
\hline Roof Construction & $\begin{array}{l}120 \mathrm{~mm} \text { glass wool, felt, } 120 \mathrm{~mm} \\
\text { polyurethane }\end{array}$ \\
\hline Doors & Metal Insulating (2”w/urethane) \\
\hline
\end{tabular}

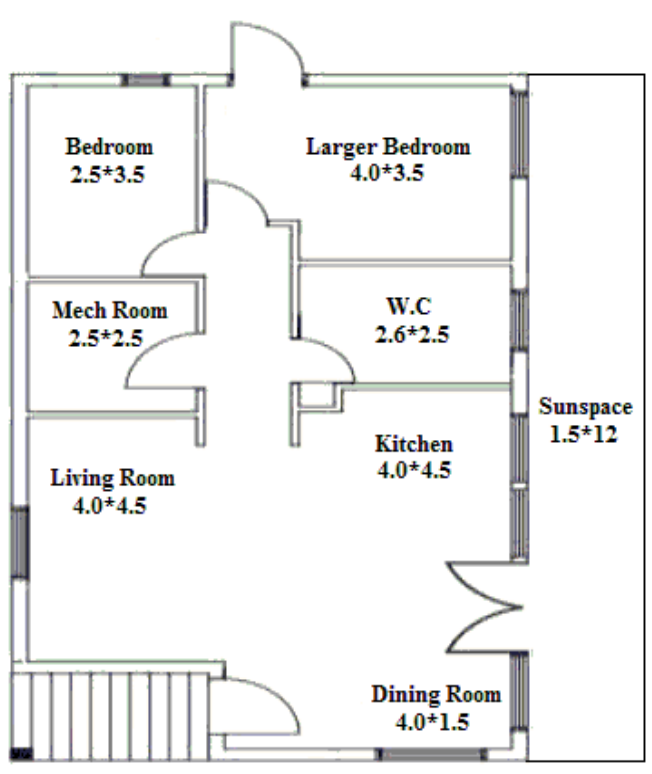

Fig. 3. House plan (m)

\section{B. Domestic Hot Water, Heating and Cooling Systems}

One of the main aspects of ZEBs is designing an appropriate domestic hot water, heating and cooling systems with respect to the available radiation. In order to evaluate the possible choices, it was concluded that low efficiency of PVs brings about a huge cost to supply the compressor electricity used in the compression cycles. Furthermore, environmental issues such as Ozone Depletion Potential (ODP) and Global Warming Potential (GWP) as well as intangible costs lead us to choose the absorption unit as mechanical system [4]. Details of the designed absorption heat pump with a common stratified tank in order to provide hot water demand as well are available at [3].

In order to assign collectors' type and surface area, energy demand profile for hot water, cooling and heating should be compared with available hourly total solar radiation on the tilted surface which is available at [3]. In this way, utilizability is defined as a radiation statistic that represents the fraction of the total radiation which is received at an intensity higher than a critical level [5]. As a result, total utilizable energy in Tehran is calculated in order to assign the absorption chiller capacity and type of the collectors. It is important to note that the design procedure in this way is quite iterative since the absorbed and utilizable energy depend on the collector type and characteristics [6].

Table III summarizes the results for the calculated monthly average hourly utilizable energy in the daylight hours for Tehran which represents a cold and a warm month. Note that the data is symmetrical after the solar noon. 
TABLE II: UTILIZABLE ENERGY IN DAYLIGHT HOURS

\begin{tabular}{l|llllll}
\hline & $6-7$ & $7-8$ & $8-9$ & $9-10$ & $10-11$ & $11-12$ \\
\hline January & 0 & 0.2649 & 0.7041 & 0.7959 & 0.8317 & 0.8456 \\
\hline July & 0.6348 & 0.7553 & 0.8096 & 0.8382 & 0.8536 & 0.8604 \\
\hline
\end{tabular}

With assumed collector characteristics, useful gain per unit surface area is calculated. These values in conjunction with heat pump coefficient of performance (COP) constitute the available energy which should satisfy cooling and heating loads during the year.

Monthly energy demand for space heating and cooling is obtained by curve fitting according to total annual heating and cooling load and measured load peak. The achieved results are 1.5 ton for heating and 1.8 ton for cooling. Furthermore it should be mentioned that total annual space heating load is $0.824 \mathrm{GJ}$ and annual cooling load is $1.008 \mathrm{GJ}$. In order to obtain the hourly demand profile, the curve fitting is carried out in concern with the assumption of negligible load in March and October. Fig. 4 shows the results for three different collector surface areas. The available energy from collectors is a design parameter which has to meet the average demand for all of months.

Note that the auxiliary system using PV cells compensates the shortage during one day. Comparing the results for several collector areas, it can be concluded that $21 \mathrm{~m}^{2}$ (three evacuated collectors with each area of $3 \mathrm{~m}^{2}$ has been utilized along with four flat-plate collectors with $4 \mathrm{~m}^{2}$ surface area) is sufficient to meet the average cooling and heating needs.

The existence of an electrical auxiliary system is essential in the days in which the amount of sunlight is not sufficient or its duration is so short that the storage tank is not able to supply the whole day's need. Fig. 5 shows the difference between gain and demand. In the hours in which this amount is negative, auxiliary system has to be used along with storage to meet the demand.

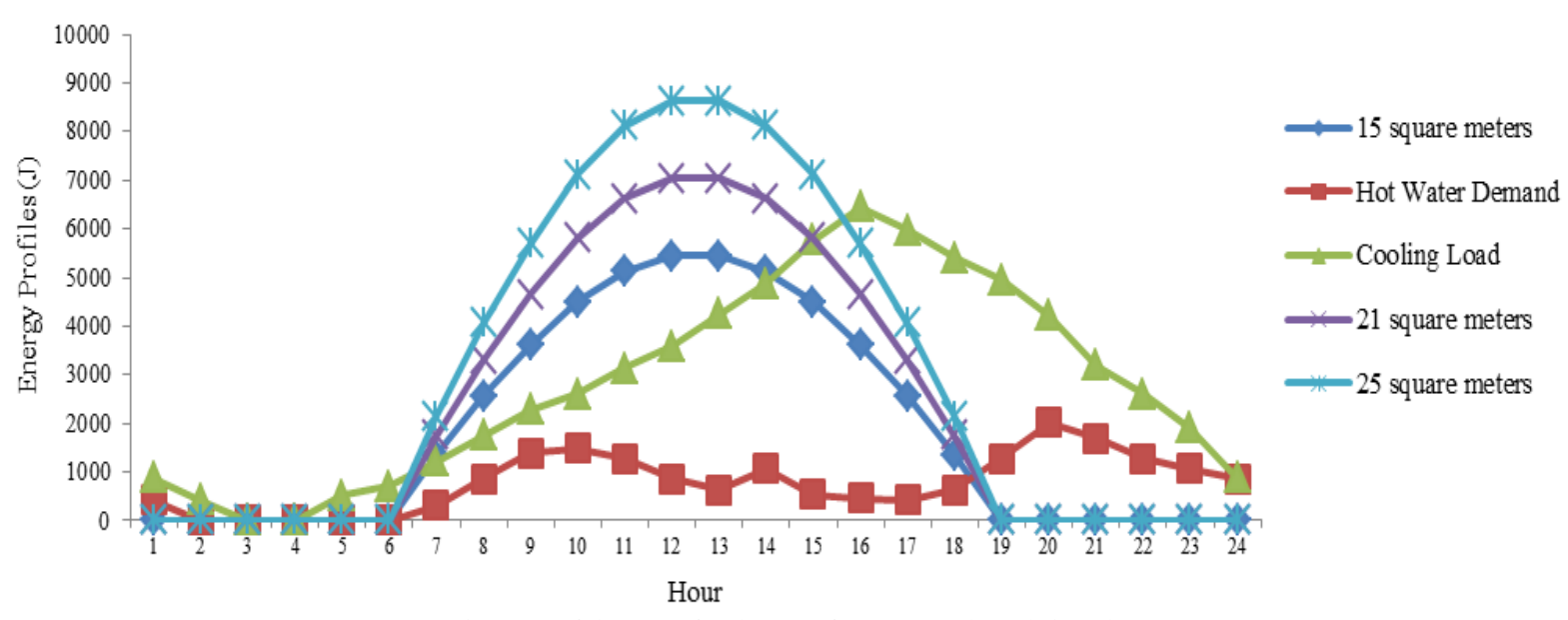

Fig. 4. Useful energy for three surface area and needs in July.

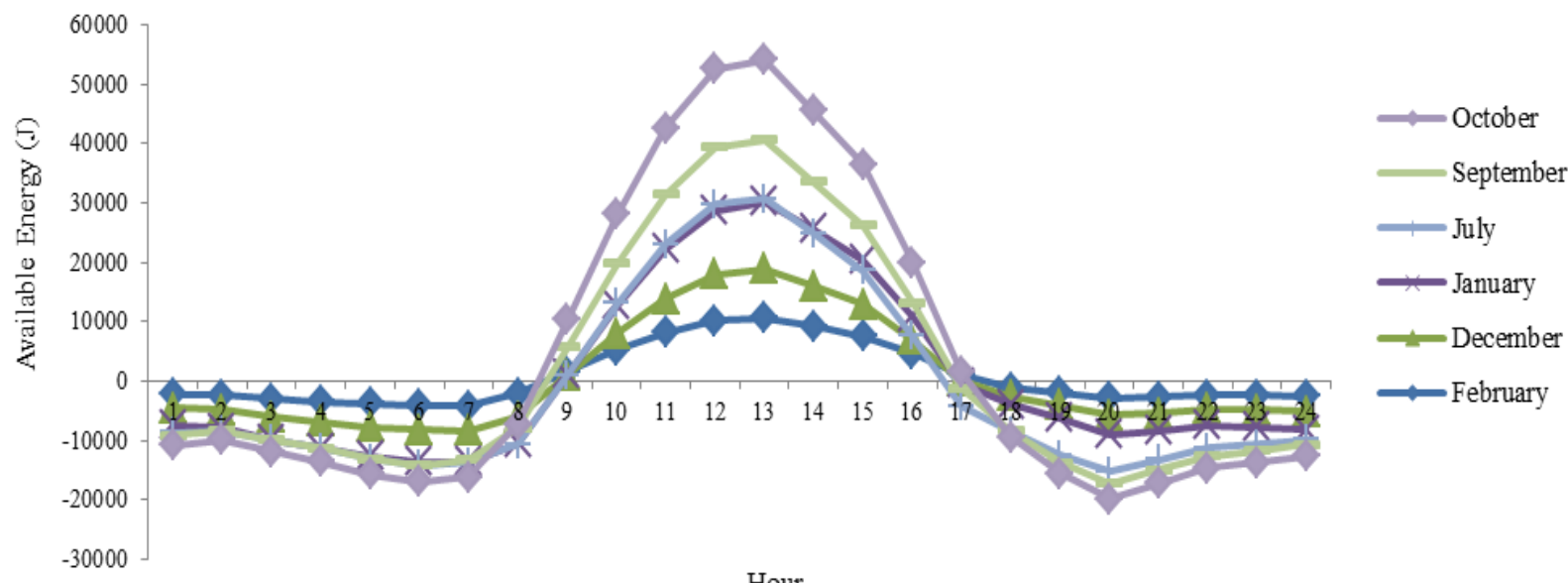

Fig. 5. Difference of useful energy and demand for some months.

\section{Lighting and Electricity Storage}

LEDs and fiber optics has been used in all zones of the house. Power demands of these tools are about 165 Watts [3].

The system has been designed to provide the whole electricity demands. Annual electric demands for electrical appliances, lighting and HVAC auxiliary systems are 4673 $\mathrm{kW} \cdot \mathrm{h}$, and for providing this demand, 32 photovoltaic modules with 220 rated powers has been utilized [3]. The distribution of power generation during the year has been shown in Fig. 6. Also, Fig. 6 shows the comparison between total power generation and total electric loads.

To choose the number of batteries to provide the requirement for critical months according to weather reports, a risk factor has been assumed for electricity load [3], [7]. The green columns in Fig. 6 illustrate the monthly electricity load by considering risk factor. By taking all the aforementioned data into account, four batteries have been selected with total capacity of $1600 \mathrm{~A} \cdot \mathrm{h}$ to store the produced electricity [3]. 


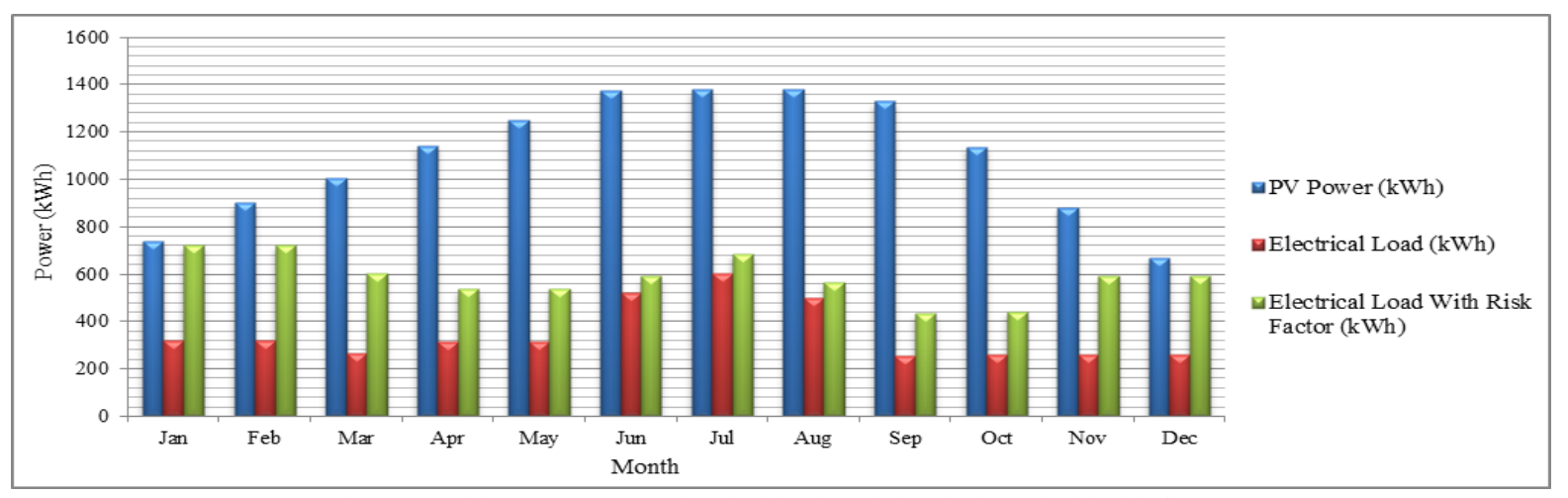

Fig. 6. Monthly output power, electrical load, and electrical Load with risk factor.

\section{POLlUtant AND GREENHOUSE GAS EMISSIONS}

This section presents an environmental analysis of using solar ZEBs as a substitute for conventional homes. First, direct evaluation is conducted with achieved data about generation of pollutants and greenhouse gases due to usage of natural gas in buildings. Then, an indirect evaluation about electricity usage is done. That is, reduction of the amount of electricity generation at thermal power plants and its subsequent pollutants and greenhouse gases is evaluated.

\section{A. Natural Gas}

As a universal standard, usage of different energy suppliers is stated with equivalent number of barrels of crude oil. In Iran 318.1 million barrels of equivalent crude oil is consumed in residential, public and commercial buildings via natural gas. Regarding the proportion of residential usage, it can be determined that 135.51 million barrels of crude oil is the total consumption of houses. One of the main features of ZEB is omission of energy usage in the form of natural gas. Heating systems and cooking devices contribute the major part of this usage in Iran. Consumption of natural gas in such different areas for a typical residential house has created many environmental problems. Conventional heating systems especially those incorporating combustion process produce a large amount of pollutants and greenhouse gases which endangers the human life in long span. Table IV shows the amount of produced gases due to domestic use of natural gas for a typical year in Iran.

TABLE III: Amount of PRODUCED PollutANTS Due to DOMESTIC USE OF

\begin{tabular}{l|ll}
\multicolumn{3}{|c}{ NATURAL GAS } \\
\hline Polluting Gas & $\begin{array}{l}\text { Dissipation Rate (tons/year) } \\
\text { Residential, Public and } \\
\text { Commercial buildings }\end{array}$ & $\begin{array}{l}\text { Dissipation } \\
\text { Rate(tons/year) } \\
\text { Residential Buildings }\end{array}$ \\
\hline $\mathrm{NO}_{\mathrm{X}}$ & 100984 & 43019.184 \\
\hline $\mathrm{SO}_{2}$ & 404 & 172.104 \\
\hline $\mathrm{CO}$ & 13532 & 5764.632 \\
\hline $\mathrm{SPM}$ & 9644 & 4108.344 \\
\hline $\mathrm{CO}$ & 109195926 & 46517464.5 \\
\hline $\mathrm{CH}_{4}$ & 1946 & 828.996 \\
\hline $\mathrm{N}_{2} \mathrm{O}$ & 195 & 83.07 \\
\hline
\end{tabular}

The absorption heat pump and PV panels utilizing clean solar energy could wipe out these amounts of pollutants and greenhouse gases. Therefore, regarding the number of families in Iran, role of each family can be investigated in this matter. In the other word by calculating quota of house in average, effect of utilizing each ZEB as a substitute for conventional homes is revealed.

From the socioeconomic point of view, it is worth noting that social cost is defined as the cost which is imposed from devastative effects of pollutants on the ecosystems, crops, and human health. For instance, the social cost of carbon is meant to be a comprehensive estimate of climate change damages and includes, but is not limited to, changes in net agricultural productivity, human health, and property damages from increased flood risk [8]. Unfortunately, it is not usually taking into account in the final price. With respect to mentioned costs by Environmental Energy Review (EER) -Iran, this intangible cost could be analyzed approximately. Table V summarizes the investigations in order to obtain dissipation rate of pollutants and greenhouse gases and social costs per each house in Iran.

In conclusion, each house impose 197149 Rials overall as the social cost to environment and community.

TABLE IV: Social COSTS Evaluation OF THE Pollutants

\begin{tabular}{l|lll}
\hline $\begin{array}{l}\text { Polluting } \\
\mathrm{Gas}\end{array}$ & $\begin{array}{l}\text { Dissipation Rate } \\
(\mathrm{kg} / \text { family.year) }\end{array}$ & $\begin{array}{l}\text { Social Cost } \\
(1000 \text { Rials/ton) }\end{array}$ & $\begin{array}{l}\text { Social Cost } \\
\text { (Rials/family.year) }\end{array}$ \\
\hline $\mathrm{NO}_{\mathrm{X}}$ & 2.0778 & 4800 & 9973.6 \\
\hline $\mathrm{SO}_{2}$ & 0.0083 & 14600 & 121.4 \\
\hline $\mathrm{CO}$ & 0.2784 & 1500 & 417.6 \\
\hline $\mathrm{SPM}$ & 0.1984 & 34400 & 6826.1 \\
\hline $\mathrm{CO}_{2}$ & 2246.79 & 80 & 179743.3 \\
\hline $\mathrm{CH}_{4}$ & 0.04004 & 1680 & 67.3 \\
\hline $\mathrm{N}_{2} \mathrm{O}$ & 0.00401 & $*$ & $*$ \\
\hline
\end{tabular}

\section{B. Electricity and Lighting}

In Iran, the electrical usage in the residential buildings is $56773.7 \mathrm{GW} \cdot \mathrm{h}$ which $30.87 \%$ of whole usage is. All these amounts of electricity are generated in the power plants which are one of the largest producers of pollutants and greenhouse gases [1]. Therefore, there is a close relationship between electricity usage and air pollution produced by power plants. Hence, in order to calculate the amount of polluting gases which are produced indirectly in residential buildings by power plants, the simple way, but not the accurate one, is to multiply the percent of electricity consumption in residential buildings by the amount of pollutants and greenhouse gases that are produced in power plants. The results are shown in Table VI. 
TABLE V: Amount of Produced Pollutants Due to Domestic Use of ELECTRICITY [1]

\begin{tabular}{|c|c|c|c|}
\hline $\begin{array}{l}\text { Polluting } \\
\text { Gas }\end{array}$ & $\begin{array}{l}\text { Total } \\
\text { Dissipation Rate } \\
\text { (kg/family.year) } \\
\text { by Powerplants }\end{array}$ & $\begin{array}{l}\text { Dissipation Rate } \\
\text { (kg/family.year) } \\
\text { Using Electricity } \\
\text { in Residential } \\
\text { Buildings }\end{array}$ & $\begin{array}{l}\text { Social Cost } \\
\text { (Rials/family.year) }\end{array}$ \\
\hline $\mathrm{NO}_{\mathrm{X}}$ & 31.3 & 9.7 & 46354.7 \\
\hline $\mathrm{SO}_{2}$ & 34.9 & 10.8 & 157487.7 \\
\hline $\mathrm{CO}$ & 7.3 & 2.3 & 3399.0 \\
\hline SPM & 1.5 & 0.5 & 16059.1 \\
\hline $\mathrm{CO}_{2}$ & 8137.2 & 2512.0 & 200985.2 \\
\hline $\mathrm{CH}_{4}$ & 0.2 & 0.06 & 98.5 \\
\hline $\mathrm{N}_{2} \mathrm{O}$ & 0.03 & 0.01 & * \\
\hline
\end{tabular}

In this calculation it is assumed that the amounts of electricity used in the residential buildings are the same one produced in the power plants. However, it is obvious that because of transmission losses, more power is required to be generated in the power plants to provide the specified amounts to be utilized in houses. Therefore it is found out that 424384Rials is imposed on society in term of electricity usage.

\section{CONCLUSION}

In this paper, environmental features of a zero energy building which is designed in Tehran on February 2012, is investigated. Design requirements for such homes are described as the first step. This building using renewable energy source is capable of providing electric power, heating, cooling. Therefore, it can play an effective role in reduction of pollutant and greenhouse gas emissions, $25 \%$ of which is produced by buildings in Iran. Natural gas usage and its environmental impacts are studied directly and it is found out that about $2247 \mathrm{~kg} \mathrm{CO}_{2}$ is released in average by each family per year. On the other hand, share of electricity usage in pollutants is analyzed indirectly by evaluating the amounts of pollutants which are produced in power plants. It is revealed that $2512 \mathrm{~kg} \mathrm{CO}_{2}$ will be wiped out per each family by constructing ZEB. Furthermore, these environmental features are studied from another important point of view. With socioeconomic perspective, social costs of different pollutants due to residential use of natural gas and electricity are obtained. Investigations indicate 621533 Rials is total social costs.

\section{REFERENCES}

[1] Energy Balance Sheet, Ministry of Energy of Iran, 2012.

[2] F. Asdrubali, F. Cotana, and A. Messineo, "On the evaluation of solar greenhouse efficiency in building simulation during the heating period," Energies, vol. 5, pp. 1864-1880, June 2012.

[3] N. Mirkhani, J. Eshraghi, S. Sadoughi, N. Narjabadi, and A. Nakhaei, "Designing a zero energy building for Tehran," presented at the International Conference for Enhanced Building Operations, Manchester, England, October 23-26, 2012.

[4] N. Mirkhani, S. Sadoughi, and A. Nakhaei, "Economic and environmental study of solar absorption chillers in domestic applications," in Proc. 2nd National Conference on Environmental Planning and Management, Tehran, 2012, pp. 504.

[5] A. A. Duffie and W. A. Beckman, Solar Engineering of Thermal Processes, 3rd ed. Hoboken, U.S.A.: Wiley, 2006, ch. 2, pp. 45-47.

[6] L. Wang, J. Gwilliam, and P. Jones, "Case study of zero energy house design in UK," Energy and Buildings, vol. 41, issue 11, pp. 1215-1222, July 2009.
[7] World Weather Information Service. (2012).Weather information for Tehran. [Online]. Available: http://worldweather.wmo.int

[8] United States Environmental Protection Agency. The Social Cost of Carbon. [Online]. Available: http://epa.gov/

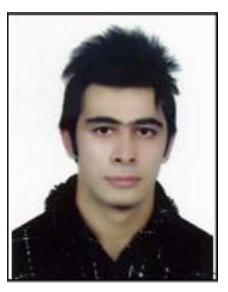

Javad Eshraghi was born in Tehran, Iran, on December 12, 1990. Eshraghi was graduated from Allame Helli high school (NODET-National Organization for Developing Exceptional Talents) and was awarded full scholarship to the University of Tehran for Undergraduate Program on September 2009. Now, Eshraghi is a bachelor of science in mechanical engineering from University of Tehran (graduated: 2013).

In last 2 years, he was the manager of University of Tehran team which is preparing for the Solar Decathlon. Solar Energy, Heat transfer and Optimization of thermal systems are his fields of interest and most of his publications are in solar energy. He was the member of "Vehicle, Fuel and Environment Research Institute" in University of Tehran. He worked at OIEC group as a summer job last year. Also he has a patent about a portable solar cooker. He is also a member of APCBEES.

Mr. Eshraghi has recently awarded Full scholarship to the University of Tehran for graduate program.

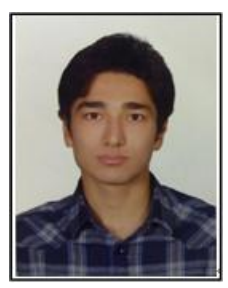

Nima Mirkhani was born in Tehran, Iran, on April 25, 1991. Mirkhani is a bachelor of science in mechanical engineering from university of Tehran (graduated: 2013). His research interests are numerical and experimental fluid flow, solar energy and optimization of thermal systems.

He was a junior research scientist at Vehicle, Fuel, and Environment Research Institute for last three years and now working in Hydraulic Turbomachinery Research Institute at University of Tehran as a research assistant. Fluid modeling and design optimization is his ongoing works. He is a member of APCBEES.

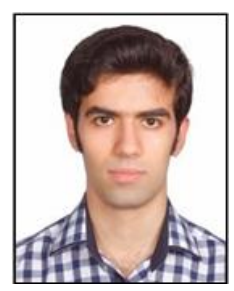

April 2011.
Nima Narjabadifam was born in Maragheh, East Azerbaijan, Iran, on May 27, 1991. Narjabadifam is Bachelor of Science in Mechanical Engineering from university of Tehran (graduated: 2013). His research interests are Renewable Energies, Numerical and Experimental Fluid Flow, and Combustion and Jet Propulsion.

$\mathrm{He}$ is a junior research assistant at Vehicle, Fuel, and Environment Research Institute (VFERI) from

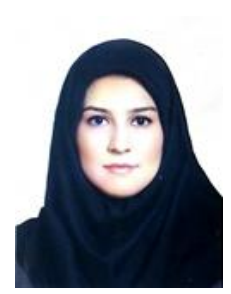

Saghi Sadoughi was born in Tampa, Florida, United States, On August 13, 1991. Sadoughi was graduated from Farzanegan high school (NODET-National Organization for Developing Exceptional Talents) and was awarded full scholarship to the University of Tehran for Undergraduate Program on September 2009. Now, Sadoughi is a bachelor of science in mechanical engineering from University of Tehran (graduated: 2013).

In last 2 years, she was a member of University of Tehran team which is preparing for the Solar Decathlon. Her research interests are biomechanics, solar energy, heat transfer and optimization of thermal systems.

Ms. Sadoughi has recently awarded fellowship to the University of California, Berkeley for graduate program.

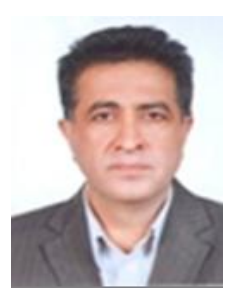

Mehdi Ashjaee is a professor of Mechanical Engineering at University of Tehran. He received his $\mathrm{Ph} . \mathrm{D}$. in mechanical engineering from University of Wisconsin-Madison in 1984.

$\mathrm{He}$ is the head of energy conversion area at Mechanical Engineering Department. His fields of expertise are convective heat transfer, thermal power plants and solar energy.

Professor Ashjaee has published many papers in international journals and recognized in his fields of interest. 